\author{
KAROL RĘBISZ \\ https://doi.org/10.33995/wu2020.2.6
}

\title{
Glosa do uchwały składu 7 sędziów Sądu Najwyższego z dnia 2 września 2019 roku [III CZP 99/18) [Glosa aprobująca]
}

Celem niniejszego artykułu jest omówienie Uchwały składu 7 sędziów Sqqu Najwyższego z dnia 2 września 2019 roku [sygn. III CZP 99/18 [OSNC 2020/2/13]]. Uchwała została podjęta na wniosek Rzecznika Finansowego w zwiqzku z rozbieżnościami w orzecznictwie sqdów powszechnych. Omawiana uchwała dotyczy zasadności zwrotu kosztów prywatnej opinii biegłego (ekspertyzy) przez ubezpieczyciela w ramach obowiqzkowego ubezpieczenia odpowiedzialności cywilnej posiadaczy pojazdów mechanicznych. Wocenie autora Sad Najwyższy prawidłowo wskazał, że poszkodowanemu oraz cesjonariuszowi roszczeń odszkodowawczych przysługuje zwrot kosztów ekspertyzy od ubezpieczyciela odpowiedzialności cywilnej. Warto jednak uzupełnić rozważania Sqqu Najwyższego poprzez omówienie kwestii niezbędności ekspertyzy i dodanie kilku uwag dotyczqcych cesji wierzytelności odszkodowawczych.

Słowa kluczowe: prywatna opinia biegłego, poszkodowany, cesjonariusz, roszczenia odszkodowawcze.

$* * *$

Glosowana uchwała stanowi rozstrzygnięcie zagadnienia prawnego przedstawionego Sądowi Najwyższemu we wniosku Rzecznika Finansowego z dnia 16 listopada 2018 roku. Rzecznik postawił Sądowi Najwyższemu następujące pytania:

1. czy koszt prywatnej ekspertyzy rzeczoznawcy poniesiony przez poszkodowanego w celu ustalenia wysokości szkody badź odpowiedzialności ubezpieczyciela w toku postępowania likwidacyjnego (przedsadowego) podlega kompensacie w ramach odpowiedzialności gwarancyjnej ubezpieczyciela z tytułu umowy obowiązkowego ubezpieczenia odpowiedzialności cywilnej posiadaczy pojazdów mechanicznych? 
2. czy analogicznej kompensacie w powyższym zakresie podlega również koszt prywatnej ekspertyzy rzeczoznawcy poniesiony przez cesjonariusza, który nabył od poszkodowanego wierzytelność odszkodowawczą?

Sąd Najwyższy w uchwale (w składzie siedmiu sędziów) uznał, że poszkodowanemu oraz cesjonariuszowi roszczeń odszkodowawczych z tytułu obowiązkowego ubezpieczenia odpowiedzialności cywilnej posiadaczy pojazdów mechanicznych przysługuje od ubezpieczyciela odpowiedzialności cywilnej zwrot kosztów tzw. prywatnej opinii [ekspertyzy] rzeczoznawcy, jeżeli jej sporządzenie było niezbędne do efektywnego dochodzenia odszkodowania.

I.

Już na wstępie, co do zasady, należy podzielić stanowisko Sadu Najwyższego odnośnie do rozstrzygnięcia zakresu obowiązku odszkodowawczego ubezpieczyciela, zarówno wobec poszkodowanych, jak i wobec cesjonariuszy wierzytelności ubezpieczeniowych, co ma istotne znaczenie dla praktyki dochodzenia roszczeń.

W uzasadnieniu wniosku Rzecznik Finansowy wskazał na rozbieżności stanowisk sądów w sprawach z obowiązkowego ubezpieczenia odpowiedzialności cywilnej posiadaczy pojazdów mechanicznych w kwestii zasądzania zwrotu wydatków poniesionych przez poszkodowanych bądź cesjonariuszy na sporządzenie prywatnej opinii (ekspertyzy) rzeczoznawcy w toku postępowania likwidacyjnego. Oddalając roszczenia o zwrot kosztów tego rodzaju opinii, sądy najczęściej negowały istnienie związku przyczynowego pomiędzy wypadkiem a kosztami opinii. Wskazywano, że koszty dotyczą opinii, która stanowi jedynie część argumentacji przygotowawczej do procesu, ale nie są kosztami postępowania ani wydatkami, o jakich mowa w art. 826 § 4 k.c. ${ }^{1}$

Dotychczas w orzecznictwie Sąu Najwyższego oraz w doktrynie ${ }^{2}$ przeważało stanowisko o zasadności zwrotu kosztów prywatnej opinii. Mimo że było to zbieżne ze stanowiskiem Rzecznika Finansowego, uznał on jednak dotychczasowe orzecznictwo za niewystarczające dla rozwiania watpliwości i zapewnienia pełnej ochrony poszkodowanym. Rzecznik wielokrotnie wcześniej występował o zmiany w systemie likwidacji szkód. Już kilka lat temu, w jednym z raportów, Rzecznik uznał za zasadne zaangażowanie niezależnego rzeczoznawcy na etapie przedsądowego dochodzenia roszczeń, jeżeli poszkodowany miałby zastrzeżenia do wyceny przedstawionej przez zakład ubezpieczeń i podtrzymanej w postępowaniu reklamacyjnym ${ }^{3}$.

Zdaniem Rzecznika Finansowego w takiej sytuacji poszkodowany będzie mógł zlecić weryfikację wyceny zakładu ubezpieczeń przez niezależnego rzeczoznawcę. Jeżeli opinia rzeczoznawcy będzie odmienna, zakład ubezpieczeń będzie mógłja podważyć jedynie poprzez powołanie innego niezależnego rzeczoznawcy. W przypadku gdy niezależny rzeczoznawca powołany przez zakład

1. Ustawa z dnia 23 kwietnia 1964 r. - Kodeks cywilny (tekst jedn. Dz. U. 2019, poz. 1145, z późn. zm.), dalej: k.c.

2. Zob. m.in. M. Kaliński, [w:] System prawa prywatnego, Prawo zobowiqzań - część ogólna. Tom VI, Olejniczak A. [red.], CH Beck, Warszawa 2009, s. 114; A. Wąsiewicz, M. Orlicki, Koszt usługi likwidacji szkody jako element odszkodowania z tytułu ubezpieczenia odpowiedzialności cywilnej posiadaczy pojazdów mechanicznych, „Prawo Asekuracyjne” 1999, nr 3, s. 4-11.

3. Raport Rzecznika Finansowego Wytyczne nadzorcze w sprawie likwidacji szkód komunikacyjnych a praktyki zakładów ubezpieczeń, Warszawa 2017. 
ubezpieczeń nie wykaże istotnego błędu w opinii rzeczoznawcy powołanego przez poszkodowanego, zakład ubezpieczeń będzie zobowiązany do zapłaty kwoty wyliczonej w opinii sporządzonej na zlecenie poszkodowanego oraz do pokrycia kosztów sporzadzenia takiej opinii ${ }^{4}$. Wydaje się, że ta bez watpienia ciekawa idea wymaga zmian legislacyjnych, poprzez stosowny zapis w przepisach ustawy o ubezpieczeniach obowiązkowych z 2003 roku $^{5}$.

II.

Sąd Najwyższy w całości podzielił stanowisko Rzecznika Finansowego wyrażone we wniosku. Przede wszystkim Sąd uznał, iż uzasadnione i konieczne koszty sporządzenia prywatnej opinii rzeczoznawcy mieszczą się w granicach normalnego związku przyczynowego, wyznaczonych zgodnie z art. 361 § 1 k.c. W uzasadnieniu Sąd Najwyższy odwołał się do swoich wcześniejszych orzeczeń, takich jak uchwała (?) z dnia 13 marca 2012 roku (sygn. akt: III CZP 75/11) - odnośnie do kosztów pomocy osoby wykwalifikowanej, uchwała z dnia 18 maja 2004 roku (sygn. akt: III CZP 24/04) - odnośnie do kosztów ekspertyzy wykonanej na zlecenie poszkodowanego, uchwała (?) z dnia 29 maja 2019 roku (sygn. akt III CZP 68/18) - odnośnie do zwrotu kosztów ekspertyzy cesjonariuszowi oraz uchwała (?) z dnia 17 listopada 2011 roku (sygn. akt: III CZP 5/11) - odnośnie do zwrotu kosztów najmu pojazdu zastępczego.

Sạd Najwyższy powiązał zwrot kosztów prywatnej opinii rzeczoznawcy z zasadą pełnego odszkodowania (art. 361 § 2 k.c.), pod warunkiem ustalenia normalnego związku przyczynowego pomiędzy zleceniem takiej ekspertyzy a wypadkiem komunikacyjnym. Przesłanką zasadności zwrotu kosztów opinii prywatnej jest niezbędność opinii do efektywnego dochodzenia roszczeń. Tak więc, nie każda opinia będzie uznana za niezbędną do efektywnego dochodzenia odszkodowania, a zatem każde roszczenie będzie rozpatrywane indywidualnie. Jak się wydaje, efektywne dochodzenie roszczenia o zwrot kosztów opinii może mieć miejsce, jeżeli w wyniku procesu - bądź przed jego wszczęciem ${ }^{6}$ - zasadna okaże się wypłata odszkodowania w kwocie wyższej niż kwota przyznana w postępowaniu likwidacyjnym, bądź zasadne okaże się odszkodowanie, którego wcześniej odmówiono.

Warto zwrócić uwagę, że Sąd Najwyższy uznał, iż koszt sporządzenia prywatnej opinii stanowi element szkody, a zatem nie jest kosztem postępowania, jak sugerowały niektóre orzeczenia sądów powszechnych? Mimo iż orzeczenia takie pojawiały się sporadycznie, glosowana uchwała jednoznacznie opowiada się przeciwko takiemu rozwiązaniu.

Sạd Najwyższy podkreślił, że gwarancyjna odpowiedzialność ubezpieczyciela, pomimo modyfikacji, nie może być odrywana od ogólnych zasad odpowiedzialności odszkodowawczej. Co do zasady odpowiedzialność ubezpieczyciela jest tożsama z odpowiedzialnością ubezpieczonego sprawcy

4. https://www.rf.gov.pl/sprawy-biezace/Raport_Rzecznika_Finansowego _o_OC_komunikacyjnym_22664 [dostęp: 5.05.2020].

5. Ustawa z dnia 22 maja 2003 roku o ubezpieczeniach obowiązkowych, Ubezpieczeniowym Funduszu Gwarancyjnym i Polskim Biurze Ubezpieczycieli Komunikacyjnych (tekst jedn. Dz. U. 2019, poz. 2214), dalej: u.u.o.

6. Nic nie stoi na przeszkodzie, aby zakład ubezpieczeń jeszcze przed wstapieniem na drogę sądową zweryfikował swoje stanowisko w związku z otrzymaną ekspertyzą.

7. Zob. wyrok Sądu Rejonowego w Tarnobrzegu z dnia z dnia 8 listopada 2017 r, sygn. akt: V GC 222/16 (niepublikowany). 
szkody, co wymaga uwzględnienia zasady pełnego odszkodowania. Odpowiedzialność ubezpieczyciela jest ograniczona jedynie do wysokości sum gwarancyjnych (art. 36 u.u.o.), zresztą relatywnie wysokich. Mimo to niektórzy autorzy wysuwają zarzut, że sama regulacja prawna sumy gwarancyjnej może stanowić zagrożenie dla interesów osób poszkodowanych.

III.

Kluczową kwestią omawianej uchwały jest uzależnienie roszczeń odszkodowawczych poszkodowanych i cesjonariuszy od „niezbędności” sporządzonej opinii dla efektywnego dochodzenia roszczeń. Wydaje się, że kryterium to może być problematyczne i trudne do wykazania. W uzasadnieniu uchwały SN wskazał, że w ocenie tego kryterium należy uwzględniać całokształt okoliczności sprawy. Zwrot kosztów sporządzenia opinii prywatnej można uznać za zasadny, jeżeli jej zlecenie było celowe i racjonalne z punktu widzenia efektywnej realizacji roszczeń z tytułu wypadku. Sąd Najwyższy nie wskazał wszak wyznaczników, które mogłyby znaleźć zastosowanie w zbliżonych stanach faktycznych, choć takimi wyznacznikami są z pewnością zasady ogólne prawa cywilnego, a zwłaszcza prawa odszkodowawczego.

W sytuacji, gdy poszkodowany nie czuje się usatysfakcjonowany wysokościa przyznanego odszkodowania, sporządzenie prywatnej opinii wydaje się uzasadnione przy założeniu, że nie dysponuje on specjalistyczną wiedza. Odwołując się do definicji „szkody”, rozumianej jako uszczerbek w dobrach prawnie chronionych, wyrażający się w uszczupleniem aktywów lub zwiększeniem pasywów ${ }^{9}$, można stwierdzić, że koszt prywatnej opinii rzeczoznawcy mieści się w pojęciu szkody. W sytuacji, gdyby nie doszło do szkody komunikacyjnej, nie powstałaby (w konsekwencji) szkoda w postaci kosztów opinii (ekspertyzy), a zatem zajście wypadku jest warunkiem sine qua non zlecenia sporządzenia takiej opinii ${ }^{10}$.

Sąd Najwyższy słusznie przyjałł, że zlecenie przez poszkodowanego ekspertyzy rzeczoznawcy na potrzeby dochodzenia roszczeń ubezpieczeniowych ma pozostawać w związku przyczynowym z wypadkiem. Problem, czy zlecenie ekspertyzy stanowi normalne następstwo wypadku. Za normalne następstwa zdarzenia, z którego wynikła szkoda, należy uznać takie następstwa, które takie zdarzenie w ogóle jest w stanie wywołać w zwykłym biegu rzeczy, a nie wskutek szczególnego zbiegu okoliczności ${ }^{11}$. Ustalenie, czy dany skutek stanowi normalne następstwo zdarzenia, nie wymaga stwierdzenia, że jest to skutek typowy, czyli zazwyczaj występujacy. Wystarczy stwierdzenie, że zwiększa się prawdopodobieństwo jego wystapienia ${ }^{12}$. Nieliczne osoby mają odpowiednia wiedzę techniczną i rozeznanie w kosztach usług naprawczych i cenach części zamiennych, aby

8. Zob. M. Orlicki, Ubezpieczenia obowiqzkowe, Wolters Kluwer, Warszawa 2011, s. 444-452.

9. Tak m.in. Sąd Najwyższy w uchwale z dnia 18 maja 2004 r. sygn. III CZP 24/04 [OSNC 2005 nr 7-8, poz. 117), w wyroku z dnia 16 maja 2002 r., sygn. V CKN 1273/00 (LEX nr 55515) oraz uchwale z dnia 15 listopada 2001 r., sygn. III CZP 68/01 (OSNC 2002, nr 6, poz. 74).

10. Zob. M. Krajewski Szkoda na mieniu wynikajaca z wypadków komunikacyjnych, Instytut Wymiaru Sprawiedliwości, Warszawa 2017, s. 80.

11. Por. B. Fuchs, Komentarz do art. 361 k.c., [w:] Kodeks cywilny. Komentarz. Tom III. Zobowiqzania. Część ogólna (art. 353-534), [red.] M. Fras, M. Habdas, Wolters Kluwer, Warszawa 2018, LEX.

12. A. Olejniczak, Komentarz do art. 361 k.c., [w:] Kodeks cywilny. Komentarz. Tom III. Zobowiqzania - część ogólna, [red.] A. Kidyba, LEX 2018. 
samodzielne stwierdzić zaniżenia odszkodowania, toteż szkoda w postaci kosztów ekspertyzy pozostaje normalnym następstwem wypadku wywołującego szkodę.

Zdaniem Sądu Najwyższego, wyjątek stanowią poszkodowani prowadzạcy działalność gospodarczą oraz dysponujący wiedzą lub kadrą i sprzętem, pozwalającymi bez pomocy osób trzecich ocenić rozmiar uszkodzeń pojazdów, przy czym wymagania te dotyczą zarówno ekspertyzy dotyczącej rozmiaru szkody powypadkowej, jak również ekspertyzy zleconej w celu wykazania odpowiedzialności ubezpieczyciela. Niewatpliwie trudno byłoby wykazać przedsiębiorcy prowadzącemu warsztat naprawczy, trudniącemu się naprawą samochodów, że potrzebował dodatkowo pomocy biegłego. Taka sytuacja mogłaby stanowić przyczynienie się poszkodowanego do zwiększenia rozmiaru szkody. Problematyczna może być sytuacja, gdy poszkodowanym jest np. mechanik zakładu naprawczego, wykorzystujący w pracy narzędzia oraz sprzęt zapewniany przez pracodawcę. Mechanik może nie być zorientowany np. odnośnie do cen części zamiennych, skoro dostarcza je pracodawca. Rozstrzygnięcie takich sytuacji wymaga uwzględnienia indywidualnych okoliczności i odwołania się sędziego do własnego poczucia prawnego ${ }^{13}$.

\section{IV.}

Warto zwrócić uwagę na oddzielenie kwestii zasadności zwrotu kosztów opinii od badania wysokości tych kosztów. Takie ujęcie pozwala na zakwestionowanie w toku postępowania sądowego nie tylko zasadności zwrotu kosztów opinii, ale także wysokości żądanej kwoty. Nie ma przeszkód, aby zakwestionować wysokość kosztów sporządzenia opinii w sytuacji, gdyby przewyższały wysokość szkody głównej, jaką najczęściej jest uszkodzenie pojazdu.

Uchwała nie rozstrzyga sposobu określenia wysokości kosztów opinii, które miałyby podlegać refundacji przez zakład ubezpieczeń. Zasadne wydaje się tu odwołanie do zasad ogólnych prawa cywilnego (np. normalne następstwa szkody), a pomocnym może okazać się orzecznictwo w kwestii zasadności najmu pojazdu zastępczego, które przyjęło, że stawki najmu pojazdu zastępczego powinny odpowiadać stawkom na rynku lokalnym ${ }^{14}$. Analogicznie, w braku innych wskazań, o wysokości kwoty żądanej przez poszkodowanego lub cesjonariusza za sporządzenie opinii powinny decydować kryteria rynkowe, a więc stawki stosowane przez ekspertów na rynku lokalnym, przy uwzględnieniu skomplikowania problemu oraz nakładu pracy.

Problematyczna może okazać się regulacja sumy gwarancyjnej. Przepis art. 15 u.u.o. nie przewiduje możliwości zastosowania postanowień umowy lub warunków ubezpieczenia korzystniejszych dla ubezpieczającego, w przeciwieństwie do przepisu art. 826 § 4 k.c., który taką możliwość dopuszcza. W doktrynie podnosi się, że aktualna treść art. 15 u.u.o. może być uznana za sprzeczną z art. 9 ust. 1 Dyrektywy Parlamentu Europejskiego i Rady 2009/103/WE z dnia 16 września 2009 roku w sprawie ubezpieczenia od odpowiedzialności cywilnej za szkody powstałe w związku z ruchem pojazdów mechanicznych i egzekwowania obowiązku ubezpieczania

13. Zob. Uchwała Sądu Najwyższego z dnia 29 maja 2019 r., sygn. III CZP 68/18 (OSNC 2019/10/98); wyrok Sądu Apelacyjnego w Łodzi z dnia 6 lutego 2014 r., sygn. I ACa 1003/13 (LEX nr 1438076); wyrok Sądu Najwyższego z dnia 6 lipca 2011 r., sygn. I CSK 512/09 (LEX nr 950712).

14. Zob. Uchwała Sądu Najwyższego (?) z dnia 17 listopada 2011 r., sygn. III CZP 5/11. 
od takiej odpowiedzialności, który dopuszcza możliwość ustanowienia przez państwa członkowskie wyższych sum gwarancyjnych ${ }^{15}$.

W kontekście problematyki sumy gwarancyjnej powstaje problem, czy świadczenie podstawowe i świadczenia dodatkowe, takie jak koszty sporządzenia opinii prywatnej, są objęte jednym limitem ${ }^{16}$. W systemie prawnym ubezpieczeń nie ma podstaw do uznania, iż świadczenia dodatkowe powinny być pokrywane ponad sumę gwarancyjna. Również art. 15 u.u.o. nie zawiera regulacji w tym zakresie, co prowadzi do wniosku, że świadczenia podstawowe oraz dodatkowe są limitowane jedną suma gwarancyjną. Problematyczne może okazać się określenie, w jakiej kolejności ubezpieczyciel powinien zaspokajać świadczenia, gdy suma gwarancyjna nie wystarcza na zaspokojenie wszystkich świadczeń. Jest to problem, który został już szeroko poruszony w literaturze ${ }^{17}$, jednak warto go zasygnalizować w kontekście zasadności zwrotu kosztów prywatnej opinii biegłego.

\section{V.}

Odnosząc się do drugiego zagadnienia sformułowanego we wniosku Rzecznika Finansowego, Sąd Najwyższy uznał, że cesjonariuszowi wierzytelności ubezpieczeniowej tak samo, jak poszkodowanemu, przysługuje uprawnienie dochodzenia od ubezpieczyciela zwrotu kosztów prywatnej opinii. Uzasadniając swe stanowisko, Sąd Najwyższy przywołał swą uchwałę (?) z dnia 29 maja 2019 r. (III CZP 68/18), która uznała zasadność zwrotu kosztów ekspertyzy zleconej osobie trzeciej, jeżeli jej sporządzenie było w okolicznościach sprawy niezbędne do efektywnego dochodzenia roszczeń odszkodowawczych. W uchwale tej Sąd Najwyższy szczegółowo omówił kwestię cesji wierzytelności w kontekście zwrotu kosztów prywatnej opinii. Zdaniem Sądu, jeżeli poszkodowany poniósł koszty takiej opinii przed umową cesji wierzytelności, roszczenie o zwrot kosztów przechodzi na cesjonariusza wraz z wierzytelnościa główną. Wynika to z art. 509 § 2 k.c., zgodnie z którym wraz z wierzytelnością przechodzą na nabywcę wszelkie związane z nią prawa. Innymi słowy, prawa akcesoryjne w stosunku do wierzytelności dziela jej los prawny ${ }^{18}$.

Jeżeli cesjonariusz zleci sporządzenie opinii już po zawarciu umowy cesji, roszczenie o zwrot kosztów opinii będzie jego własnym roszczeniem. Jednym z celów omawianej uchwały jest uznanie prawa cesjonariusza do zwrotu kosztów ekspertyzy właśnie w takim przypadku. Jak już wcześniej wspomniano, gdy poszkodowany przed dokonaniem przelewu wierzytelności zamówił opinię prywatną, roszczenie o zwrot kosztów tej opinii przechodzi na cesjonariusza wraz z wierzytelnościa główną. Jeżeli cesjonariusz samodzielnie zlecił sporządzenie ekspertyzy, która miała na celu sprawdzenie prawidłowości wysokości przyznanego odszkodowania, przyznanie mu zwrotu kosztów ekspertyzy będzie zależne od tego, czy jej sporządzenie było niezbędne do efektywnego dochodzenia odszkodowania.

15. M. Krajewski Ubezpieczenie odpowiedzialności cywilnej według kodeksu cywilnego, Wolters Kluwer, Warszawa 2011.

16. Ibidem.

17. Ibidem.

18. Zob. G. Sikorski, Komentarz do art. 509 k.c., [w:] Kodeks cywilny. Komentarz, [red.] J. Ciszewski, P. Nazaruk, Wolters Kluwer, Warszawa 2019. 
Podobnie jak w przypadku poszkodowanego występującego z własnym roszczeniem, tak w przypadku cesjonariusza od jego specjalizacji, sprzętu, wiedzy i kwalifikacji będzie zależała ewentualna odmowa zwrotu kosztów opinii. Należy zgłosić wątpliwości, czy odnośnie do cesjonariusza prowadzącego działalność gospodarczą, która polega na nabywaniu, a następnie dochodzeniu roszczeń odszkodowawczych od ubezpieczycieli, zwrot kosztów zlecenia prywatnej opinii jest rzeczywiście uzasadniony.

Sam fakt prowadzenia przez cesjonariusza wspomnianej wyżej działalności nie wyklucza a limine możliwości dochodzenia przez niego od ubezpieczyciela kosztów zleconej ekspertyzy, ale wpływa na ocenę takiego uprawnienia w poszczególnych przypadkach dochodzenia roszczeń nabytych od poszkodowanego ${ }^{19}$. Przy badaniu zasadności takiego uprawnienia należy pamiętać o konieczności wykazania związku przyczynowego pomiędzy wypadkiem komunikacyjnym a zleceniem sporządzenia ekspertyzy, szczególnie gdy ekspertyza została pozyskana przez cesjonariusza po dokonaniu przelewu wierzytelności. W takiej sytuacji zlecenie sporządzenia ekspertyzy nie zawsze będzie normalnym następstwem wypadku. Problem dotyczy w szczególności tzw. kancelarii odszkodowawczych, prowadzących usługi w zakresie realizacji roszczeń odszkodowawczych, de facto zbieżne z działalnością wykonywana przez zawody prawnicze ${ }^{20}$. Od początku pojawienia się na rynku takich „kancelarii” podnosi się konieczność ustawowego uregulowania ich działalności ${ }^{21}$, chociażby w celu objęcia ich obowiązkowym ubezpieczeniem odpowiedzialności cywilnej22.

Trudno uznać za niezbędną zlecona przez kancelarię ocenę opłacalności cesji, niezależnie od tego, czy zlecenie miało miejsce przed zawarciem, czy po zawarciu umowy przelewu wierzytelności. Wynika to z faktu, iż taka opinia nie pozostaje w adekwatnym związku przyczynowym z wypadkiem komunikacyjnym

Kancelarie odszkodowawcze, wyspecjalizowane w dochodzeniu roszczeń odszkodowawczych, zwłaszcza z tytułu ubezpieczeń komunikacyjnych, często zatrudniają specjalistów z dziedziny techniki samochodowej, co czyni zbędnymi zewnętrzne opinie. Kancelarie są więc przygotowane do samodzielnej oceny i weryfikacji zasadności i wysokości odszkodowań. Wydaje się zatem, że roszczenia kancelarii - jako cesjonariusza - o zwrot kosztów opinii trzeba traktować z duża ostrożnością. Niekiedy można je potraktować jako nieuzasadnione powiększanie rozmiaru szkody.

Na marginesie należy zwrócić uwagę na postulat zakazu cesji wierzytelności z tytułu czynów niedozwolonych, który w szczególności dotknąłby kancelarie odszkodowawcze. Taki postulat znalazł się m.in. w przygotowanym przez Senat IX kadencji projekcie ustawy o świadczeniu usług w zakresie dochodzenia roszczeń odszkodowawczych wynikających z czynu niedozwolonego ${ }^{23}$.

19. Uchwała Sądu Najwyższego z dnia 29 maja 2019 r., sygn. III CZP 68/18 (OSNC 2019, nr 10, poz. 98).

20. E. Kowalewski, M. Ziemiak, W sprawie legalności ubezpieczeniowych kancelarii odszkodowawczych, „Prawo Asekuracyjne" 2011, nr 1, s. 19.

21. Ibidem, s. 19; P. Chrościński, Sprawozdanie z konferencji „Kancelarie odszkodowawcze jako uczestnicy rynku ubezpieczeniowego - wczoraj, dziś i jutro, „Wiadomości Ubezpieczeniowe” 2015, nr 2, s. 162; K. Krawczyk, A. Daszewski, Kancelarie odszkodowawcze z perspektywy Rzecznika Ubezpieczonych, „Monitor Ubezpieczeniowy" 2009, nr 37, s. ?.

22. Zob. W. Mogilski, Przesłanki i założenia postulowanego ubezpieczenia odpowiedzialności cywilnej doradców i kancelarii odszkodowawczych, [w:] Doradztwo odszkodowawcze w Polsce. Potrzeba regulacji prawnej, [red.] E. Kowalewski, Toruń 2015, s. 121 i nast.

23. Senacki projekt ustawy o świadczeniu usług w zakresie dochodzenia roszczeń odszkodowawczych wynikajacych z czynu niedozwolonego (Sejm VIII kadencji, druk nr 3136). 
Projekt zawierał propozycję kompleksowego uregulowania działalności doradców i kancelarii odszkodowawczych, w tym objęcie ich obowiązkowym ubezpieczeniem OC. Postulowany zakaz przelewów wierzytelności odszkodowawczych mógłby zagrażać interesom poszkodowanych, m.in. z uwagi na praktykowany bezgotówkowy najem pojazdów zastępczych. Taki najem pojazdu - bez watpienia korzystny dla poszkodowanych - w pewnym stopniu wymusza cesję wierzytelności odszkodowawczej, pozostawiając dochodzenie odszkodowania „wypożyczalni”. Wprowadzenie bezwzględnego zakazu cesji wykluczałoby możliwość bezgotówkowego rozliczania szkód, co mogłoby osłabiać poziom ochrony poszkodowanych.

Reasumując, należy całkowicie podzielić stanowisko Sądu Najwyższego, które zresztą zostało zaaprobowane zarówno przez Rzecznika Finansowego, jak i przedstawicieli doktryny. Warto zwrócić uwagę na realistyczną formułę przyjęta w uchwale SN, która nie daje poszkodowanym ani cesjonariuszom powszechnego i bezwzględnego prawa żądania zwrotu kosztów opinii, lecz ogranicza roszczenia do przypadków, w których opinia rzeczoznawcy jest rzeczywiście niezbędnym warunkiem efektywnego dochodzenia roszczeń, co oczywiście należy wykazać i uzasadnić.

\section{Wykaz źródeł}

Chrościński P., Sprawozdanie z konferencji „Kancelarie odszkodowawcze jako uczestnicy rynku ubezpieczeniowego - wczoraj, dziś i jutro, „Wiadomości Ubezpieczeniowe” 2015, nr 2.

Fuchs B., Komentarz do art. 361 k.c., [w:] Kodeks cywilny. Komentarz. Tom III. Zobowiqzania. Część ogólna (art. 353-534], Fras M., Habdas M. [red.], Wolters Kluwer, Warszawa 2018.

Kaliński M., [w:] System prawa prywatnego. Prawo zobowiqzań - część ogólna. Tom VI, Olejniczak A. [red.], CH Beck, Warszawa 2009.

Kowalewski E., Ziemiak M., W sprawie legalności ubezpieczeniowych kancelarii odszkodowawczych, „Prawo Asekuracyjne” 2011, nr 1.

Krajewski M., Szkoda na mieniu wynikajaca z wypadków komunikacyjnych, Instytut Wymiaru Sprawiedliwości, Warszawa 2017.

Krajewski M., Ubezpieczenie odpowiedzialności cywilnej według kodeksu cywilnego, Wolters Kluwer, Warszawa 2011.

Krawczyk K., Daszewski A., Kancelarie odszkodowawcze z perspektywy Rzecznika Ubezpieczonych, „Monitor Ubezpieczeniowy” 2009, nr 3 ?.

Olejniczak A., Komentarz do art. 361 k.c., [w:] Kodeks cywilny. Komentarz. Tom III. Zobowiqzania - część ogólna, Kidyba A. [red.], Wolters Kluwer, Warszawa 2018.

Orlicki M., Ubezpieczenia obowiqzkowe, Wolters Kluwer, Warszawa 2011.

Raport Rzecznika Finansowego Wytyczne nadzorcze w sprawie likwidacji szkód komunikacyjnych a praktyki zakładów ubezpieczeń, Warszawa 2017.

Senacki projekt ustawy o świadczeniu usług w zakresie dochodzenia roszczeń odszkodowawczych wynikających z czynu niedozwolonego (Sejm VIII kadencji, druk nr 3136).

Sikorski G., Komentarz do art. 509 k.C., [w:] Ciszewski J., Nazaruk P., Kodeks cywilny. Komentarz, Wolters Kluwer, Warszawa 2019.

Wąsiewicz A., Orlicki M., Koszt usługi likwidacji szkody jako element odszkodowania z tytułu ubezpieczenia odpowiedzialności cywilnej posiadaczy pojazdów mechanicznych, „Prawo Asekuracyjne" 1999, nr 3. 


\section{Gloss to resolution of the Supreme Court of 2 September 2019, court file no. III CZP 99/18}

The purpose of this article is to comment on the Supreme Court resolution dated 2nd September 2019, court file no. III CZP 99/18 (OSNC 2020/2/13) and adopted by 7 judges, which was passed at the request of the Financial Ombudsman in connection with the discrepancies in case law. The commented resolution concerns the legitimacy of reimbursement of private opinion costs by the insurer as part of the compulsory vehicle liability insurance. In the author's opinion, Supreme Court correctly indicated that the injured party and the assignee of compensation claims are entitled to reimbursement of expertise costs from the civil liability insurer. It is worth supplementing the considerations of the Supreme Court by commenting on the need for private opinion and adding a few remarks regarding the assignment of compensation claims.

Key words: private opinion, injured party, assignee, compensation claims.

MGR KAROL RĘBISZ - prawnik, absolwent Uniwersytetu Rzeszowskiego

e-mail:krebisz@poczta.onet.pl 
